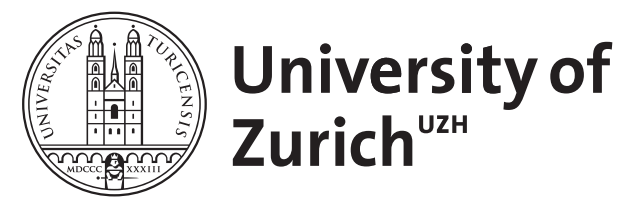

Zurich Open Repository and Archive

University of Zurich

University Library

Strickhofstrasse 39

CH-8057 Zurich

www.zora.uzh.ch

Year: 2007

Obesity and other clinical endpoints in steroid-sensitive nephrotic syndrome

Neuhaus, Thomas J ; Rüth, Eva-Maria ; Kemper, Markus

DOI: https://doi.org/10.1007/s00467-006-0362-5

Posted at the Zurich Open Repository and Archive, University of Zurich

ZORA URL: https://doi.org/10.5167/uzh-156653

Journal Article

Published Version

Originally published at:

Neuhaus, Thomas J; Rüth, Eva-Maria; Kemper, Markus (2007). Obesity and other clinical endpoints in steroid-sensitive nephrotic syndrome. Pediatric Nephrology, 22(3):471.

DOI: https://doi.org/10.1007/s00467-006-0362-5 


\title{
Obesity and other clinical endpoints in steroid-sensitive nephrotic syndrome
}

\author{
Thomas J. Neuhaus • Eva-Maria Rüth • \\ Markus Kemper
}

Received: 21 August 2006 / Accepted: 2 September 2006 / Published online: 7 December 2006

(C) IPNA 2006

Sirs,

We read with great interest the article of Foster et al. [1] on risk factors for glucorticoid-induced obesity in children with steroid-sensitive nephrotic syndrome (SSNS). The prevalence of obesity in patients with remote SSNS was high with $20 \%$, however, not significantly different from the prevalence in the reference group. We have recently reported a comprehensive long-term study on 42 adults treated for childhood SSNS, providing also a detailed analysis of growth [2]. The median BMI was $23 \mathrm{~kg} / \mathrm{m}^{2}$; in five women and three men the BMI was $>25$, and only one female was obese, with a BMI of 31.4. No correlation was found between height and weight in adulthood and the cumulative prednisone dose or duration of prednisone administration. The epidemic of being overweight and obese appears to be more prevalent in the US than in some European countries. We suggest to add to the conclusion of

T. J. Neuhaus $(\bowtie)$

Leiter Nephrologie/Poliklinik, Universitäts-Kinderklinik,

Steinwiesstrasse 75 ,

Zürich 8032, Switzerland

e-mail: Thomas.Neuhaus@kispi.unizh.ch

E.-M. Rüth

Pediatric Nephrology, University Children's Hospital,

Zürich, Switzerland

\section{Kemper}

Nephrology, University Children's Hospital,

Hamburg, Germany
Foster's report that the prevalence of persistent obesity in children with SSNS is also correlated with the local prevalence or epidemic of obesity in the healthy reference group.

Also, other clinical endpoints seem to differ in various geographical areas. Hegarty et al. [3] reported a high prevalence of bone fractures in adults treated with steroids for childhood SSNS in the UK: Of the 24 male and 10 female subjects, $19(79.2 \%)$ and $3(30 \%)$, respectively, had suffered a total of 43 self-reported fractures. In contrast, only $2(5 \%)$ of the 42 patients in our study had sustained a single bone fracture although our patients were not given calcium or vitamin D supplements.

We propose that the long-term outcome and clinical endpoints in steroid-sensitive idiopathic nephrotic syndrome not only depend on treatment regimens and therapy responsiveness, but also on regional circumstances, lifestyles and living conditions.

\section{References}

1. Foster BJ, Shults J, Zemel BS, Leonard MB (2006) Risk factors for glucocorticoid-induced obesity in children with steroid-sensitive nephrotic syndrome. Pediatr Nephrol 21:973-980

2. Rüth E-M, Kemper MJ, Leumann EP, Laube GF, Neuhaus TJ (2005) Children with steroid-sensitive nephrotic syndrome come of age: long-term outcome. J Pediatr 147:202-207

3. Hegarty J, Mughal MZ, Adams J, Webb NJA (2005) Reduced bone mineral density in adults treated with high-dose corticosteroids for childhood nephrotic syndrome. Kidney Int 68:2304-2309 